\title{
Renewable Energy Resources in Nigeria: Sources, Problems and Prospects
}

\author{
C. N. Ezugwu
}

\begin{abstract}
As a result of the danger posed to the environment by fossil fuels, the world is shifting towards low carbon energy to be powered by new energy sources. Nigeria is endowed with abundance of renewable energy (RE) resources. Being rich in energy resource, it is regrettable that Nigeria is yet to exploit these huge available energy potentials with less environmental and climatic impacts. There is need to conserve the nation's trees and other forestry resources so as to make the government's reforestation, soil erosion and desertification control programmes successful. This paper discusses the renewable energy resources in Nigeria, its sources, characteristics, problems and prospects. Moreover, there is need to integrate this energy resource into the Nigeria energy system in view of its numerous gains.
\end{abstract}

Index Terms - Energy, renewable, resources.

\section{INTRODUCTION}

Climate change, the soaring global electricity demand, the scarcity of fossil fuels and, consequently, their rising costs, make renewable energy gain in importance. Renewable energy is that that is replaced naturally or controlled carefully and can therefore be used without the risk of finishing it all (Oxford Advanced Learner's Dictionary New 8th Edition). It is in constant supply without depletion. These new sources range from cleaner fossil fuels to renewable energy. Fossil fuels are high-carbon sources of fuel like oil, gas and coal which form the bulk of energy consumption worldwide. Renewable energy sources comprise energy mix of solar, wind, hydro, bio-mass, ocean waves and tides, and geothermal. They are 'renewables' because they are regularly replenished by natural processes and are therefore in endless supply [1]. They also can operate without adversely affecting the environment.

The present high cost of fossil energy calls for exploitation of other alternative renewable energy resources to diversity the consumption-mix of these energy resources in Nigeria so as to integrate and gainfully exploit the renewable energy resources which are bountifully available in the country. In this way, the local consumption of petroleum products will be greatly reduced, thereby making them more available for export, with resulting increases in the foreign exchange earnings of the country [2].

The uses of petroleum products within the country, apart from their uses for transportation, are mainly for electricity generation in thermal power stations, for cooking and for provision of industrial lubricants. To a large extent, the single

Manuscript received September 20, 2013; revised January 22, 2014.

C. N. Ezugwu is with the Department of Civil Engineering, Anambra State University, Uli, Nigeria (e-mail: engrcharlesezugwu@ yahoo.com). largest consumption is for electricity generation. However, this can be substantially reduced. The reduction can be made up for by the use of alternative energy resources. Of all these alternatives, the renewables are solar energy, hydropower, biomass and wind power [3]. These are highly recommended for use by their availability and ease of utilization. Resource potentials of the major renewable energy types are given in Table I.

\begin{tabular}{|c|c|c|}
\hline Resource & Potential & Reference \\
\hline Large-Scale & $10,000 \mathrm{MW}$ & \\
\hline \multicolumn{3}{|l|}{ Hydropower } \\
\hline Small-Scale & $734.2 \mathrm{MW}$ & [4] \\
\hline Hydropower & & \\
\hline Solar Radiation & $3.5-7 \mathrm{Kwh} / \mathrm{m}^{2} /$ day & [5] \\
\hline Wind & $2-4 \mathrm{~m} / \mathrm{s}$ & [6] \\
\hline Fuel wood & $\begin{array}{r}43.3 * \\
\text { tons/year }\end{array}$ & [7] \\
\hline $\begin{array}{l}\text { Animal Waste and } \\
\text { Crop Residues }\end{array}$ & $\begin{array}{c}144^{*} \\
\text { tons/year }\end{array}$ & {$[8]$} \\
\hline
\end{tabular}

Available statistics show that more than 80 per cent of the energy consumption in the world is still fossil fuels while renewable energy is put at 20 per cent. Nigeria is one of the countries that rely heavily on fossil fuel, especially oil and gas to meet its energy needs. The Nigeria Energy Policy Report estimated that less than 40 per cent of the population is connected to the national grid. The report says the grid is powered by hydro and thermal, which itself comprises of fossil fuels which are capable of emitting carbon dioxide. Nigeria is faced with the challenge of increasing energy production to meets its local demand and probably for export. The country is also faced with the challenge to develop technologies to open new sources for oil and natural gas that will be environment-friendly and emit less carbon dioxide. For Nigeria to address these challenges, it must develop its hydro potential by fully utilizing its dams and reservoirs for hydro-power generation. It is dangerous for a country to rely solely on one source of energy, but it is always good to combine it with at least four types of renewable energy (Dr. Klaus Heiddler, a German Solar Consultant).

According to Former President of Nigeria, Mathew Aremu Olusegun Obasanjo, Africa must not be de-linked from the renewable energy revolution. He added that renewable energy holds the promise for Africa's energy self-sufficiency and availability.

The energy-induced environmental degradation is already prevalent in the country [9]. This is characterized by deforestation as a result of falling of trees for fuel wood and charcoal production, air pollution in urban areas arising from vehicular emission and burning of traditional fuel for 
traditional cooking in households, noise pollution from use of small generators to provide electricity due to inadequate supply from the national grid, land and water pollution from oil spillage in the oil producing communities. This led Nigeria and indeed the world to source for alternative energy resources like solar energy, wind energy among others. Afforestation should be encouraged since the carbon in the atmosphere is used by trees thereby reducing carbon content of the environment and reducing global warning. The energy production level of any community dictates her pace of development and hence her poverty level.

\section{RENEWABLE ENERGY SOURCES IN NIGERIA}

\section{A. Solar Energy}

Nigeria has high potentials to harness energy from the Sun, being a renewable source. It falls within the tropics of Cancer and Capricorn where there is abundance of sunlight. Unlike the conventional energy resources, like fossil fuels, solar energy development is not as capital intensive. Therefore, it is fundamental to proffer the strategy of diversifying energy resource development outside the conventional energy resources. The implication is that adequate funds should be channeled towards the development of other non-conventional, less capital intensive and non-hazardous energy resources in Nigeria. With the abundance supply of solar energy in Nigeria, efforts need to be geared towards research and development of solar energy generation.

Solar energy, an energy obtained from the sun, is the world's most abundant and cheapest source of energy available from nature. It is free and automatically renewable everyday. Solar energy is available in two forms, namely Solar Thermal and Solar PV.

\section{1) Solar thermal}

This is the direct application of solar energy to produce heat. This is dated back to ages, exemplified by sun drying and so on, common in the equatorial region where people have programmed themselves to sun drying of personal effects such as clothing and drying of agricultural commodities, resulting to various researches in solar thermal equipment like cabinet dryers, oven, hatchery, water heaters among others. In Nigeria, solar thermal have been developed for various applications; some of these are solar cookers, solar pulverizers, chick brooding devices [10]. Regarding the drying of Agricultural produce, there are four major drying techniques, namely: open air drying, fire wood/fuel drying, electrical drying and solar drying [11].

\section{2) Solar PV}

Solar PV is the conversion of solar radiation to electricity using solar cells. These include its use for water pumping for Irrigation in the Rural Areas, lightings and other purposes. The United Nation Commission on Sustainable Development has called for much wider access to Sustainable energy as a prerequisite for reducing poverty to about $50 \%$ by the year 2015 as all world leaders reaffirmed in the year 2005 world summit in New York. By sustainable energy, it means energy produced and used in a way that supports human development over the long term in all its social, economic and environmental development [12]. Millennium Development Goals (MDGs) of halving poverty; will not be possible without increasing energy services, production and income, creating jobs and reducing drudgery [13], [14].

Table II below reveals the poor state of generation and supply of electricity in Nigeria and the need for alternative energy resources like solar, wind, hydro, among others.

TABLE II: COUNTRY STATISTIC OF ELECTRICITY GENERATION AND PER CAPITAL CONSUMPTION

\begin{tabular}{|c|c|c|c|c|}
\hline Continent & Country & $\begin{array}{c}\text { Population } \\
\text { (Million) }\end{array}$ & $\begin{array}{c}\text { Generation } \\
\text { Capacity }\end{array}$ & $\begin{array}{c}\text { Per-Capital } \\
\text { Consumption } \\
(\mathrm{Kw})\end{array}$ \\
\hline $\begin{array}{c}\text { North } \\
\text { America }\end{array}$ & USA & 200 & 813,000 & 3.2 \\
\hline $\begin{array}{c}\text { South } \\
\text { America }\end{array}$ & Cuba & 10.54 & 4,000 & 0.38 \\
\hline $\begin{array}{l}\text { Europe } \\
\text { Central }\end{array}$ & $\begin{array}{c}\text { United } \\
\text { Kingdom }\end{array}$ & 57.5 & 76,000 & 1.1 \\
\hline $\begin{array}{l}\text { Europe } \\
\text { Eastern }\end{array}$ & Ukraine & 49 & 54,000 & 1.33 \\
\hline $\begin{array}{c}\text { Middle } \\
\text { East } \\
\text { Far East }\end{array}$ & $\begin{array}{c}\text { Iraq } \\
\text { South Korea }\end{array}$ & $\begin{array}{l}23.6 \\
47\end{array}$ & $\begin{array}{l}4,000 \\
1,800\end{array}$ & $\begin{array}{l}0.42 \\
1.10\end{array}$ \\
\hline Africa & $\begin{array}{c}\text { Nigeria } \\
\text { Egypt } \\
\text { South Africa }\end{array}$ & $\begin{array}{l}140 \\
67.9 \\
44.3\end{array}$ & $\begin{array}{l}4,000 \\
1,800 \\
45,000\end{array}$ & $\begin{array}{l}0.03 \\
0.27 \\
1.03\end{array}$ \\
\hline
\end{tabular}

Source: [15]

\section{B. Hydro Power (Energy)}

This is energy generated from water conserved in a reservoir when a dam is constructed across flowing water like river or stream. Hydropower is generated by conversion of the potential energy of the high head water into electrical energy [16]. The water which is conveyed by the penstock is made to fall on the blades of the turbine to run them by the conversion of the hydraulic energy to mechanical energy which in turn is converted into electrical energy by directly coupling the shaft of the turbine with a generator. The generator armature thus rotated produces electricity [16].

Our country is specially endowed with large rivers and some few natural falls. Small rivers and streams also exist within the present spill of the country into eleven River Basin Authorities, some of which maintain minimum discharges all the year round. Hydropower currently accounts for about $29 \%$ of the total electrical power supply [17]. In a study carried out in twelve(12) states and four (4) river basins, over 278 unexploited small hydropower (SHP) sites with total potentials of 734.3 MW were identified [18]. However, SHP potential sites exist in virtually all parts of Nigeria with an estimated total capacity of 3,500 MW. They indicate that Nigeria possesses potential renewable source of energy along her numerous river systems, a total of 70 micro-dams, 126 mini dams and 86 small sites have been identified.

Hydropower projects in Nigeria are not without disadvantages:

1) Hydropower projects in Nigeria give birth to huge loans that lead to very high external debt levels and are plagued with allegations of corruption.

2) Construction of dams and reservoirs destroy natural ecosystem; including displacing people and wildlife.

3) Hydropower development is affected by drought especially in the Northern Nigeria; and silting of dams reduces the amount of energy that can be generated overtime. 


\section{Wind Energy}

Many countries of the world are developing wind power plants for the generation of electricity in their quest to exploit renewable energy sources. Nigeria should not be left out in this campaign. Wind energy is available at annual average speeds of about $2.0 \mathrm{~m} / \mathrm{s}$ at the coastal regions of the South and $4.0 \mathrm{~m} / \mathrm{s}$ at the far Northern region of the country. Globally, the long-term technical potential of wind energy is believed to be five times total current global energy production, or 40 times current electricity demands. This could require wind turbines to be installed over large areas, particularly in areas of higher wind resources.

In Nigeria, currently the share of wind energy in the national energy consumption has remained low and with no commercial wind power plants connected to the national grid. Only a few number of stand-alone wind power plants were installed in the early 1960s in 5 northern states mainly to power water pumps and a $5 \mathrm{kw}$ wind electricity conversion system for village electrification installed at Sayyan Gidan Gada, in Sokoto State [19]. In recent times numerous studies have been carried out to assess the wind speed characteristics and associated wind energy potentials in different locations in Nigeria. Promising attempts are being made in Sokoto Energy Research Centre (SERC) and Abubakar Tafawa Belewa University, Bauchi to develop capability for the production of wind energy technologies.

\section{Biomass Energy}

The biomass resources of Nigeria can be identified as crops, forage grasses and shrubs, animal waste arising from forestry, agriculture, municipal and industrial activities, as well as, aquatic biomass. Crops such as sorghum, maize, sugarcane were the most promising feedstocks for biofuel production [20]. Biomass (plant material) is a renewable energy source because the energy it contains comes from the sun. Through the process of photosynthesis, plants capture the sun's energy. When the plants are burnt, they release the sun's energy they contain. In this way, biomass functions as a sort of natural battery for storing solar energy.

In Nigeria, identified feedstock substrates for an economically feasible biogas production include water lettuce, water hyacinth, dung, cassava leaves and processing waste, urban refuse, solid (including industrial) waste, agricultural residues and sewage [21]. It has been estimated that Nigeria produces about 227,500 tons of fresh animal waste daily. Since $1 \mathrm{~kg}$ of fresh animal waste produces about $0.03 \mathrm{~m}^{3}$ biogas, then Nigeria can potentially produce about 6.8 million $\mathrm{m}^{3}$ of biogas every day from animal waste only. Sawdust and wood wastes are other important biomass resources associated with the lumber industry.

\section{E. Other Resources}

Presently, the potentials of some resources like geothermal, nuclear energy, waves, tidal and ocean thermal gradient still remain untapped and unquantified [15].

\section{Characteristics/Advantages OF Renewable ENERGY}

It is free, since it comes from the sun, the wind, waves etc.
It is renewable, implying that it is sustainable and will never run out, keeps coming back next day.

Its facilities require less maintenance than traditional generators. Their fuel being derived from natural and available resources reduces the cost of operation.

Renewable energy has minimal impact on the environment since it produces little or no waste products such as carbon dioxide or other chemical pollutants.

Economic benefits are attracted by renewable energy projects to areas where they are located, as most projects are located away from large urban centres and suburbs of the capital cities. These economic benefits arise from increase in the use of local services as well as being a centre for tourism.

\section{Characteristics of NON-RENEWABle ENERGY}

It comes from fossil fuels, coal, oil and natural gas.

It will not last forever.

It emits carbon dioxide and other polluting chemicals when it burns.

It contributes to greenhouse gas in the atmosphere, increasing global warming.

\section{PRoblems of RENEWABLE ENERGY}

It is difficult to generate the quantities of energy (e.g. electricity) that are as large as those produced by traditional fossil fuel generators. This suggests that we need to reduce the amount of energy we use or simply build more energy facilities.

Supply of renewable energy is unreliable. Renewable energy often relies on the weather for its source of power. For instance, hydrogenerators need rains to fill reservoirs of dams to enable sufficient head of water that can generate high power (Ezugwu, 2009). Also, wind turbines require wind to turn the blades, and solar collectors need clear sides and sunshine to collect heat and make electricity. When these resources are not available, so is the capacity to make energy from them. This can be unpredictable and inconsistent.

The current cost of renewable energy technology is also far in excess of traditional fossil fuel generation. The reason is that it is a new technology having extremely large capital cost.

\section{PROSPECTS OF RENEWABLE ENERGY IN NIGERIA}

There are many organizations within the academic, federal, and commercial sectors conducting large scale advanced research in the field of renewable energy. Most of the research is targeted at improving efficiency and increasing overall energy yields [22]. In Nigeria, there are various opportunities and conditions that favour the installation and development of solar energy, as evident in Table II. There are prospects of these renewable energy resources in our country especially in areas of solar, wind, and hydro energies. Research works in this area should be encouraged to enable provision of sufficient and reliable energies for most communities in the country. Brighter future and greater prospect abound for all renewable energy sources and there is need to incorporate them in the Nigeria National Energy Mix. 


\section{RESULT AND DISCUSSION}

The study brought in focus the various sources of renewable energy available in our country. These alternative energy sources should be integrated into our national grid in view of its numerous gains. Wind power should be used especially in Northern Nigeria where the wind velocity is high. The federal government should partner with the private sector to make these alternative energy sources available and affordable to most communities in our country.

\section{CONCLUSION}

This paper has been able to discuss the renewable energy potentials in Nigeria. There is need to harness alternative energy sources in our country to reduce dependence on fossil fuel which is not environment friendly and is exhaustible. The federal government should partner with private organizations to sponsor research in this new area in view of its numerous benefits.

\section{REFERENCES}

[1] E. Uyigue, "Dams are unrenewable," Community Research and Development Centre (CREDC), Nigeria, March, 2006.

[2] Energy Commission of Nigeria, "Rural renewable energy project, renewable and alternative energy devices and viable alternatives to fuel wood and kerosene," presented at the Joint ECN-NYSC Rural Renewable Energy Project Workshops, Dec. 1997.

[3] A. S. Sambo, "Solar and wind power for integrated rural development projects," in Proc. Seminar on Rural Development for Self Sufficiency, 1987, pp. 156-168.

[4] U. O. Aliyu and S. B. Elegba, "Prospects for small hydropower development for rural application in nigeria," Nig. J. of Ren. Energy, vol 1, pp. 74-86, 1990.

[5] J. O. Ojosu, "Solar radiation maps for Nigeria," Nig. J. of Solar Energy, vol. 8, pp. 370-384, 1989.

[6] J. O. Ojosu and Salawu, "A survey of wind energy potentials in Nigeria," Solar and Wind Technology, vol. 7, pp. 155-167, 1990.

[7] A. O. Odukwe and S. O. Enibe, "Energy resources of Nigeria," Solar and Wind Technology, vol. 5, No. 3, pp. 335-338, 1988.

[8] Federal Min. of Sc. \& Tech, "Policy guidelines on energy for Nigeria," Lagos, 1989.

[9] A. S. Sambo, "Strategic development in renewable energy in Nigeria," International Association for Energy Economics, 3rd Quarter, pp. $32-36,2009$.

[10] W. I. Okonkwo, "Passive solar heating for poultry chick brooding in Nigeria," presented at International Workshop on Renewable Energy for Sustainable Development in Africa, 2007.

[11] D. Whitefield, "Solar dryer system and the internet important resources to improve food production," presented at the International Conference on Solar Cooking, Kimberly, South Africa, 2000.
[12] UNDP, United Nations Development Programme, 2005.

[13] A. O. Jesuleye and W. O. Siyanbola, "Solar electricity demand analysis for improved access to electricity in Nigeria," Nigeria Journal of Soalr Energy, vol. 19, no. 1, pp. 136-141, 2008.

[14] A. S. Sambo, "The role of energy in achieving millennium development goals (MDGs)," Keynote Address of the National Engineering Conference, Ahmadu Bello University, Zaria, $1^{\text {st }}$ April, 2008.

[15] E. C. N. Okafor and C. K. A. Joel-Uzuegbu, "Challenges to development of renewable energy for electric power sector in Nigeria," International Journal of Academic Research, vol. 2, no. 2, pp. 211-216, 2010.

[16] C. N. Ezugwu, "Penstock as essential component of a hydropower scheme," Journal of Civil and Environmental Systems Engineering, vol. 10, no.1, pp. 34-42, 2009.

[17] V. A. Ijeoma, "Renewable energy potentials in Nigeria," presented at the $32^{\text {nd }}$ Annual Meeting of the International Association for Impact Assessment, Centro de Congresso da Alfandega, Porto-Portugal, 27 May-1 June 2012

[18] U. O. Aliyu and S. B. Elegba, "Prospects for small hydropower development for rural application in Nigeria," Nig.J of Ren. Energy, vol. 1, pp. 74-86, 1990.

[19] C. C. Uzoma, C. E. Nnaji, C. N. Ibeto, C. G. Okpara, O. O. Nwoke, I. O. Obi, G. O. Unachukwu, and O. U. Okparaku, "Renewable energy penetration in nigeria: a study of the south-east zone," Continental $J$. Environmental Sciences, vol. 5, no. 1, pp. 1-5, 2011.

[20] C. E. Nnaji, C. C. Uzoma, and J. O. Chukwu, "The role of renewable energy resources in poverty alleviation and sustainable development in Nigeria," Continental J. Social Sciences, vol. 3, pp. 31-37, 2010.

[21] J. F. K. Akinbam, "Renewable energy resources and technologies in nigeria: present situation, future prospects and policy framework," Mitigation and Adaptation Strategies for Global Change, vol. 6, pp. 155-188, 2001.

[22] S. C. E. Jupe, A. Michiorri, and P. C. Taylor, "Increasing the energy yield of generation from new and renewable energy sources," Renewable Energy, vol. 14, no. 2, pp. 37-62, 2007.

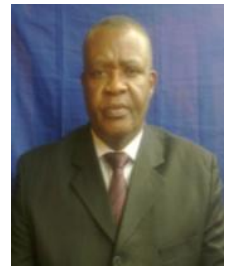

C. N. Ezugwu was born on $22^{\text {nd }}$ October, 1962 at Nsukka, Enugu State, Nigeria. He completed secondary school education at St. Theresa's Collage Nsukka in 1980 where he came out with division one grade. He obtained a bachelor degree in civil engineering at former Anambra State University of Technology in 1986. He also obtained a masters degree in water resources in Civil Engineering Department of Nnamdi Azikiwe University Awka, Anambra State Nigeria, with distinction grade in 2006. In 2013, he obtained a doctor of philosophy degree $(\mathrm{PhD})$ in water resources in Civil Engineering Department of the same University with a distinction grade.

He worked with Real Heights Limited (2001-2007) as the project manager. He also lectured at Madonna University, Elele, Nigeria (2007). Presently he is a lecturer at Department of Civil Engineering, Anambra State University, Uli, Nigeria (2007 to date). He is also an associate dean of Faculty of Engineering of the University. He has many scholarly publications and is a member of many professional societies, including Nigerian Society of Engineers (NSE) and registered by the Council for the Regulation of Engineering in Nigeria (COREN) 